Karstenia 36:47-50. 1996

\title{
A re-collection of Inonotus pruinosus Bondartsev (Basidiomycetes)
}

\author{
YU-CHENG DAI, MARGARITA A. BONDARTSEVA, BAO-YOU XU AND \\ CHENG-ZHI YU
}

\begin{abstract}
DAI, Y.C., BONDARTSEVA, M.A., XU, B.Y. and YU, C.Z. 1996: A recollection of Inonotus pruinosus Bondartsev (Basidiomycetes). Karstenia 36:47-50. Helsinki. ISSN 0453-3402

Inonotus pruinosus Bondartsev, earlier known from the type only, was re-collected from northeastern China. Its emended description is given and its taxonomic position is discussed. The fungus is characterized by its extensive pruinose basidiocarps, thick-walled and golden yellow spores and robust hyphoid setae and by living exclusively on Salix.
\end{abstract}

Key words: China, Inonotus pruinosus, polypore

Yu-Cheng Dai, Department of Ecology and Systematics, and Botanical Museum, P.O. Box 47, FIN-00014 University of Helsinki, Finland

Margarita A. Bondartseva, V.L. Komaroo Botanical Institute of the Russian Academy of Sciences, 197376 St. Petersburg, Russia

Bao-You Xu and Cheng-Zhi Yu, Forestry Institute of Tieling, Tieling, 11200, Liaoning Prov., China

\section{Introduction}

Two new specimens of the extremely rare polypore Inonotus pruinosus Bondartsev were collected from Liaoning Prov., Northeast China. This fungus was first collected by M.V. Gorlenko from China, and described by Bondartsev (1962). After the original description the species has been cited twice, by Pegler (1964) and Bondartseva and Parmasto (1986), but otherwise has remained almost forgotten. While the first author was studying the woodrotting fungi of Changbai Mts., northeastern China, in a field trip in 1995, he found Inonotus pruinosus growing on many willow trees in town of Tieling, Liaoning Prov. The specimens are ample and well developed. A study of this new material revealed that the original description is incomplete. The paper of Bondartsev (1962) contains neither drawings of any microscopical characters nor an English description. On the basis of the new collections and after a reexamination of the type we are now able to give an illustrated description of this polypore.

The specimens collected by Y.C.D. are deposited in $\mathrm{H}$ (Finland), one duplicate is deposited in LE (Russia), and one will be forwarded to HMAS (China). The microscopical routine used in the study is the same as presented by Dai (1995).

Inonotus pruinosus Bondartsev, Bot. Mater. Otd. Spor. Rast. 15: 99. 1962. Figs. 1a-e, 2.

Basidiocarps annual to perennial, resupinate, effused, adnate, inseparable, ca. $50 \mathrm{~cm}$ or more in the longest dimension, up to $40 \mathrm{~mm}$ thick at the centre, soft to fibrous when fresh, woody hard upon drying, without odour or taste. Margin up to $3 \mathrm{~mm}$ wide, thinning out, pale yellowish to dirty-coloured. Pore surface strongly pruinose and cracking when old; pores round to angular, usually sinuous when tubes grow obliquely, $2-3(-4)$ per $\mathrm{mm}(\mathrm{n}=90 / 3)$, tube 


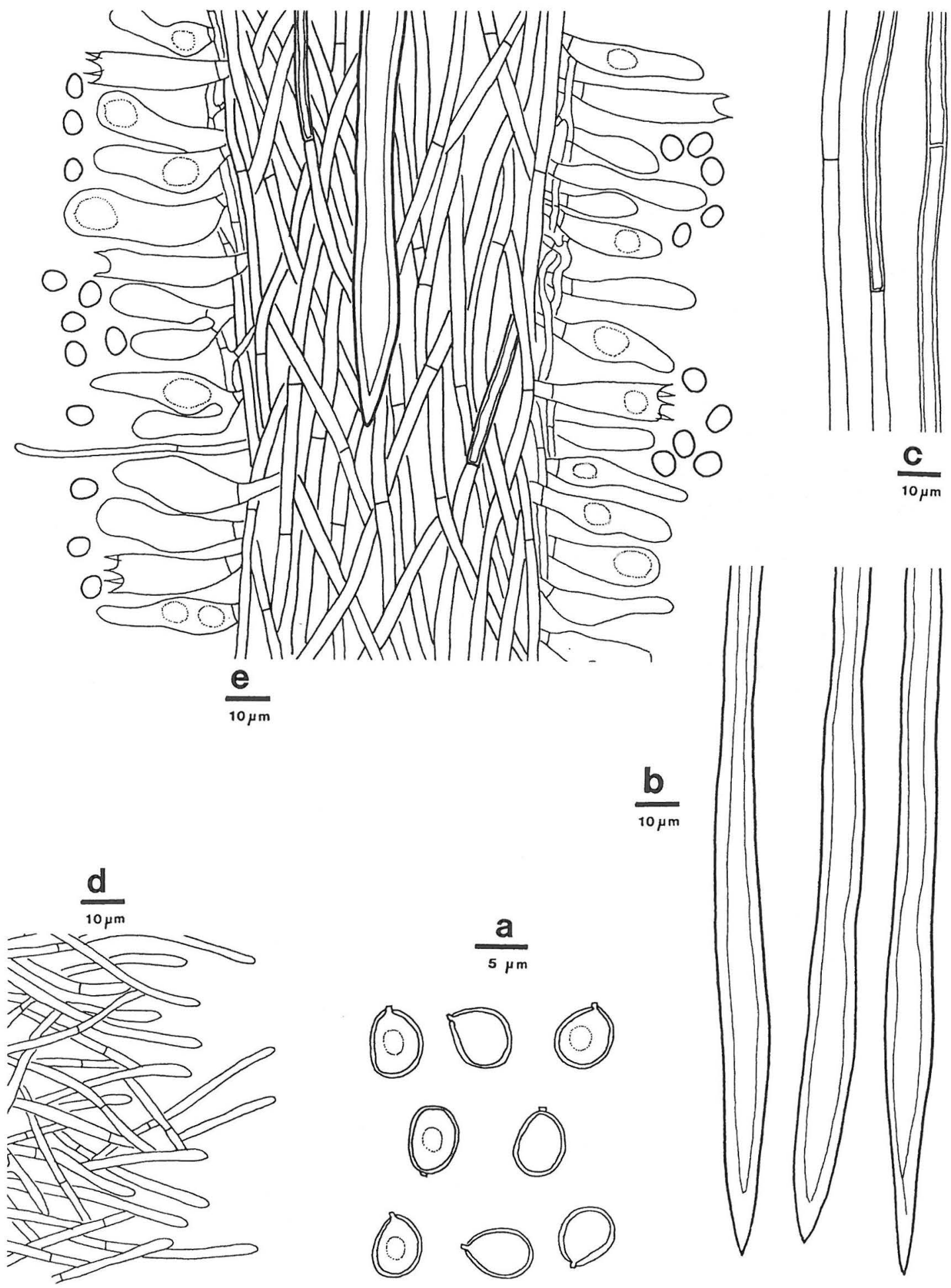

Fig. 1a-e. Microscopic structures of Inonotus pruinosus Bondartsev (drawn from Dai 1972b). a) spores, b) hyphoid setae, c) subiculum hyphae, d) secondary mycelium emerging from hymenium, e) a vertical section through trama. 


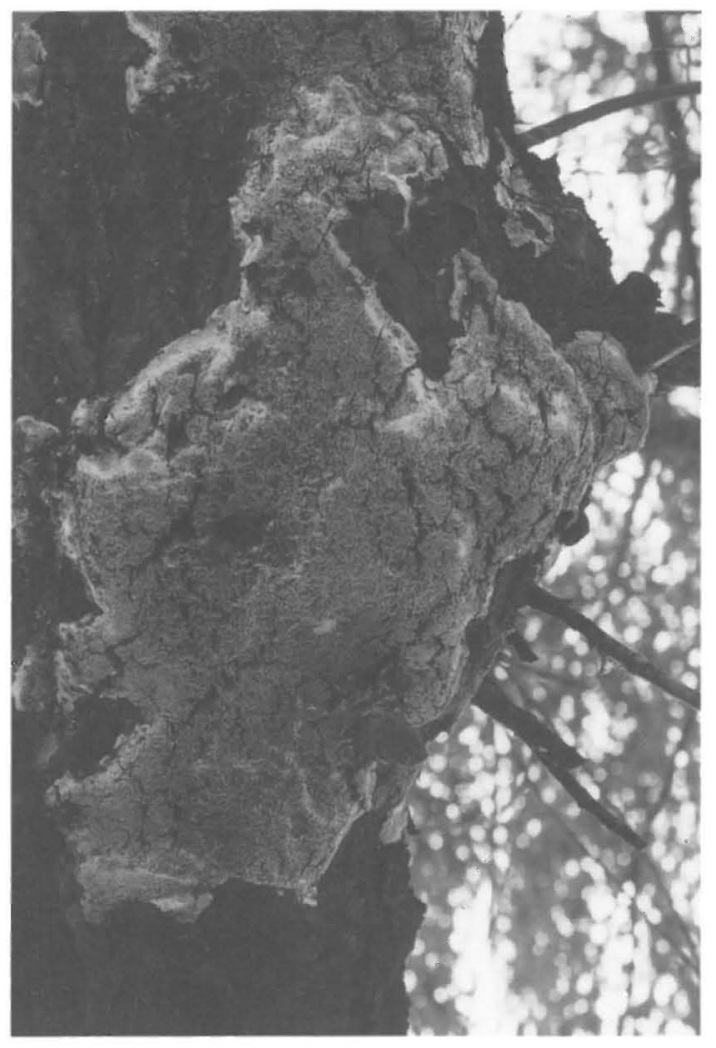

Fig. 2. Inonotus pruinosus Bondartsev. A fresh basidiocarp (Dai 2126). Photograph in situ on 23.IX.1995 by Y.C.D., $\mathrm{x} 0.3$.

mouths mostly entire, sometimes more or less lacerate, matted. Subiculum umber brown, very thin (not exceeding $1 \mathrm{~mm}$ ), fibrous to corky. Tubes yellowish brown to umber brown, having pale stripes of stuffing mycelium, fibrous to woody fragile, up to $20 \mathrm{~mm}$ long, annual layers distinct, up to 3 layers in the present material.

Hyphal system monomitic; all septa without clamp connections; tissues darkening but otherwise unchanged in $\mathrm{KOH}$.

Subiculum. As well as next to the substrate, a new subiculum develops after each annual layer of tubes. Generative hyphae aligned according to substrate, varying from yellowish and thin-walled to pale brown and fairly thickwalled, (3.5-)4-5.7(-6.5) $\mu \mathrm{m}$ in diam $(n=37 / 1)$; all transitions present. Contextual hyphoid setae scanty.

Tubes. Tramal hyphae varying from hyaline and thin-walled at dissepiment edges to yellowish or pale brown and thick-walled toward deep trama, rarely branched, parallel. Hyphoid setae prominent but not dominating, mostly parallel with the tubes and not penetrating into hymenium, dark chestnut brown, sharp-pointed, thick-walled, having a lumen that typically extends nearby to the tip, up to a few hundreds of $\mu \mathrm{m}$ long, (6-)9-13(-15) $\mu \mathrm{m}(\mathrm{n}=40 / 2)$ in diam in the widest part. Hymenial setae absent. Subhymenium indistinct; hymenium usually collapsed in old specimens, basidia clavate, having one or a few guttules, with two or four sterigmata and a simple basal septum, (15-)19-32(-34) x 5-7 $\mu \mathrm{m}$ ( $n=30 / 2)$; basidioles basically clavate, but highly variable in shape. Secondary mycelium abundant in tube cavities, its hyphae thinwalled, hyaline, frequently simple-septate and occasionally branched.

Spores. Basidiospores abundant, broadly ellipsoid to ovoid-globose, thick-walled, golden yellow, smooth, having a small guttule, negative in Melzer's reagent, slightly cyanophilous in Cotton Blue, (5.8-)6-7.4(-8) x (4.1-)4.5-6(-6.3) $\mu \mathrm{m}, \mathrm{L}=6.68 \mu \mathrm{m}, \mathrm{W}=5.08 \mu \mathrm{m}, \mathrm{Q}=1.24-1.40$ $(n=93 / 3)$.

\section{Specimens examined}

China. Liaoning Prov., on Salix, 30.VIII.1954 Gorlenko (LE 22479, holotype); Tieling, on living Salix, 5.IX.1995 Dai 1972b, 23.IX.1995 Dai 2162.

\section{Discussion}

The new collections confirm that Inonotus pruinosus may be perennial and woody hard upon drying. Although these characters point towards the genus Phellinus Quél., we retain it in Inonotus P. Karst. because of the typically monomitic hyphal structure. The demarcation between Inonotus and Phellinus is nevertheless unsatisfactory. Many species in Phellinus have, in fact, a monomitic hyphal system, but have been kept in the genus just because they are perennial and woody hard.

A group of species, sometimes included in Inonotus and sometimes in Phellinus, were separated by Dai (1995) into Phellinidium (Kotl.) Fiasson \& Niemelä. An important character of that genus is the presence of abundant hyphoid setae in the trama. The hyphal structure of Inonotus pruinosus is closely similar to that of Phellinidium, which, however, has thin-walled 
and hyaline spores. Therefore I. pruinosus cannot be included in Phellinidium.

The following species of the genus Inonotus have hyphoid setae and thick-walled, coloured spores: I. boninensis T. Hattori \& Ryvarden, I. iliensis Kravtzev, I. nidus-pici Pilát, I. ochroporus (Van der Byl) Pegler, I. patouillardii (Rick) Imaz., I. quercustris M. Blackwell \& Gilb., I. ulmicola Corfixen. Among these species I. ochroporus, I. patouillardii and I. quercustris are typically pileate and occur in tropical areas. They are easily distinguished from I. pruinosus.

Inonotus boninensis was recently described from Japan. It has slightly smaller pores (3-4 per $\mathrm{mm}$ ), wider hyphoid setae $(10-25 \mu \mathrm{m}$ in diam), and larger spores (9.5-12 x 5-7.5 $\mu \mathrm{m})$ than the present species, and grows on Persea (Hattori \& Ryvarden 1993).

Among the above-listed species the basidiocarps of Inonotus iliensis and I. nidus-pici have been found to line the cavities of hollow trunks. Their hyphoid setae sometimes project into the tube lumen. Both species have true hymenial setae, which are not abundant, however. Furthermore, the spores of these two species are thin- to slightly thick-walled. In contrast, I. pruinosus fruits on the bark of trees, its hyphoid setae are embedded in trama and not projecting, it lacks hymenial setae, and its spores are definitely thick-walled.

Inonotus ulmicola is distinguished from $I$. pruinosus in having smaller pores $(5-6$ per $\mathrm{mm})$ and larger spores $(7-10.5 \times 5.5-7.5 \mu \mathrm{m}$, Corfixen 1990), and by bearing hymenial setae.

In the genus Phellinus only P. andinus Plank \& Ryvarden has hyphoid setae and thickwalled, golden brown spores, and the species lacks hymenial setae. Its generic affinities should be reworked. It differs from Inonotus pruinosus in having smaller pores (6-7 per $\mathrm{mm})$, shorter and narrower hyphoid setae $(35-60 \times 4-7 \mu \mathrm{m})$, and larger spores (7-9 × 5.5-7 $\mu \mathrm{m}$, Plank \& Ryvarden 1982).

Inonotus pruinosus has a strongly pruinose surface and in that respect resembles I. tamaricis (Pat.) Maire. The latter, however, is typically pileate, has no hyphoid setae, and lives exclusively on Tamarix.

The type of Inonotus pruinosus is an annual specimen. Bondartsev (1962) gave somewhat larger spore dimensions than is actually the case $(7-8 \times 4.5-6 \mu \mathrm{m}$ vs. $6-7.4 \times 4.5-6 \mu \mathrm{m})$. He mentioned that $I$. andersonii (Ellis \& Everhart) Černý is similar to I. pruinosus, but it has abundant hymenial setae and is easily distinguished from the latter.

We suppose that Inonotus pruinosus is a pathogen of Salix, because the willow trees infected by the fungus appeared wilted when compared to non-infected trees.

Inonotus pruinosus is a distinctive fungus and no doubt an independent species. It is characterized by having strongly pruinose, thickwalled and golden yellow spores, by lacking hymenial setae and having hyphoid setae instead, and by living exclusively on Salix.

\section{Specimens examined for comparison}

Inonotus nidus-pici: Czech Republic. Moravia, Valtica, on Quercus, 1991 Vampola $(\mathrm{H})$. I. ulmicola: Finland. Varsinais-Suomi, Turku, on Ulmus, 1994 Blomqvist \& Häkkilä (H). I. andersonii: U.S.A. Tennessee, Grundy County, on Quercus, 1956 Lowe 20789 (H); Ohio, near Cincinnati, on ?Populus, 1895 Lloyd $(\mathrm{H})$. I. tamaricis: China. Beijing, on Tamarix, 1994 Dai 318 (H). Greece. Crete, Nomós Lasithíou, on Tamarix, 1977 Niemelä $(\mathrm{H})$.

Acknowledgements. We thank Prof. Tuomo Niemelä (Helsinki) for reviewing the manuscript. The work was financed by the Academy of Finland (Project No. 2435, 1995-1996).

\section{References}

Bondartsev, A.S. 1962: Polypori novi ex oriente extremo. Bot. Mater. Otd. Spor. Rast. 15:99-103.

Bondartseva, M.H. \& Parmasto, E.H. 1986: Clavis diagnostica fungorum URSS. Ordo Aphyllophorales 1. Familiae Hymenochaetaceae, Lachnocladiaceae, Coniophoraceae, Schizophyllaceae. 191 pp. Nauka, Leningrad.

Corfixen, P. 1990: A new species of Inonotus (Hymenochaetaceae) from Scandinavia. Nordic J. Bot. 10:451-455.

Dai, Y.C. 1995: Changbai wood-rotting fungi 3. The genus Phellinidium (Basidiomycetes) and a new species, P. aciferum. Ann. Bot. Fennici 32:63-73.

Hattori, T. \& Ryvarden, L. 1993: Polypores from Bonin Is. (Japan) 1. A new species of Inonotus (Hymenochaetaceae, Basidiomycotina). Mycotaxon 49:209-215.

Pegler, D.N. 1964: A survey of the genus Inonotus (Polyporaceae). Trans. British Mycol. Soc. 47:175195.

Plank, S. \& Ryvarden, L. 1982: Phellinus andinus Plank et Ryvarden nova sp. Mycotaxon 16:114-116.

\section{Received on 20 December 1995}

